\title{
Inclusive education and social competence development
}

\author{
Tilly Mortimore ${ }^{1}$ and Anikó Zsolnai ${ }^{2}$ \\ ${ }^{1}$ School of Education, Bath Spa University \\ ${ }^{2}$ University of Szeged, Faculty of Arts, Institute of Education, \\ University of Szeged, Social Competence Research Group
}

\begin{abstract}
Students with special educational needs are exposed to the same social and cultural effects as any other child. Their social and emotional development also evolves under those influences and they, too, must adjust to the conditions of their environment. In several cases, however, an inadequate learning environment keeps these children from experiencing and learning social skills and abilities (such as self-confidence and independence). Inclusive education for children with special educational needs is not common practice in Hungary even though it is equally well suited to fostering different social skills and abilities in children with either average or nonaverage development. This paper endeavours to argue for the importance of having inclusive education in Hungary by discussing examples abroad, with special emphasis on research and practical implementations in Great Britain.
\end{abstract}

Keywords: inclusive education, learning disabilities, social skills and abilities

\section{Introduction}

In recent decades, more and more emphasis has been placed in educational research on the study of the development of social competence. The complex system of social learning, social motives, and social abilities, skills, habits and knowledge, social competence fundamentally determines social behaviour (Nagy, 2000; RoseKrasnor, 1997; Semrud-Clikeman, 2007). People with highly developed social competence are successful in their interpersonal relationships, whereas those with underdeveloped social skills and abilities are more prone to become unsuccessful in their social life (Greene, Hariton, Robins \& Fly, 2011; Nagy, 2007; Stephens, 1992).

Social-emotional indicators, including positive interactions with teachers, positive representations of self derived from attachment relationships, emotion knowledge, emotion regulatory abilities, social skills, and nonrejected peer status, often uniquely predict academic success when other pertinent variables, even earlier academic success, are already taken into account (Denham, Blair, DeMulder, Levitas, Sawyer, Auerbach-Major \& Queenan, 2003; Izard, 2001).

The issue is especially important in the case of persons with some type of developmental disorder. We only have a partial solution to the problem of assisting the social development of children with mental and/or physical disorders even though there are methods - integration and inclusion - that are particularly suitable for this purpose. This paper looks at the potential of inclusive education in the fostering of social competence with special emphasis on children struggling with learning difficulties in general and with Learning Disability (SpLD/Dyslexia) in particular. 


\section{Development of social competence in childhood}

The childhood development of social competence is determined by a set of intrapersonal (e.g., differing cognitive and linguistic abilities, different temperaments) and a set of interpersonal factors (e.g., micro and macro-cultural environment, the family, the school, peers). Each set contains several interrelated elements (Brown, Odom \& McConnel, 2008).

\section{Intrapersonal factors}

Infants are born with a rudimentary ability to interact with their environment. Newborns track moving face-like shapes and after just a few days are able to distinguish their mother's face from other faces. The social smile appears on their face, which constantly transforms and changes in response to their carers providing appropriate feedback to them. With no adequate feedback, however, the smile will not evolve, which will then affect interactions and interpersonal relationships (Broadhead, Johnston, Tobbel \& Woolley, 2010; Cole \& Cole, 2001).

Of all individual differences, those in temperament can be recognised first. There are infants who cry more than others, and some react more sensitively to outside stimuli even at this age. Most researchers agree that temperament is rooted in biology and contains basic dispositions built into the individual. These dispositions constitute the foundations of activity, reactivity and emotionality, and regulate the expression of these personality components. Temperament refers to individual differences in behaviour that are already present at birth. These differences are clearly observable in infancy and remain relatively stable over a fairly long period, which makes them one of the starting points of social development (Denham, Bassett \& Wyatt, 2007; Thomas \& Chess, 1977). Temperament mostly manifests itself in the context of social interactions. As development progresses, the expression of temperament is increasingly influenced by experience and context (Goldsmith, 1987).

Another determinant of childhood social development are cognitive and communicative/linguistic skills and abilities. Infants and toddlers having advanced cognitive and communicative skills and abilities are at an advantage in comprehending the social world surrounding them and are better at expressing their emotions, desires and needs, which in turn assists the development of successful social interactions and relationships. These infants will appropriately modify their behaviour if necessary in response to the feedback received from their partner or partners in an interaction (Diamond, 2002; Odom, Zercher, Li, Marquart, Sandall \& Brown, 2006; Tunstall, 1994).

These skills and abilities also play an important role in social problem solving. Being able to solve problems creatively while at the same time observing both the interests of the self and those of the group has a positive effect on the development of social problem solving skills (Herbert-Myers, Guttentag, Swank, Smith \& Landry, 2006; Kasik, 2010; Odom, Zercher, Marquart, Sandall \& Brown 2006).

Finally, a further determinant of the development of social competence is infants' and toddlers' openness to their environment, to the feelings and reactions of others (Kopp \& Skrabski, 1995; Zsolnai \& Kasik, 2007; Zsolnai, 2013).

\section{Interpersonal factors}


The most important interpersonal factors are those stemming from the micro and macro-cultural environment, the family, the school environment and peer relationships.

\section{Cultural effects}

Cultural effects play a decisive role in the development of social competence since social skills and abilities clearly reflect by their nature the characteristic demands of the cultural environment. Familiarity with the relationship models in our own cultural environment is an important precondition of the evolution of efficient social relationships (Forgács, 1989; Saarni, 1999).

A range of cultural differences may be observed across different societies. One basic distinction is whether a given society has an individualist or collectivist orientation. Individualist societies emphasise individual goals and interests, while a society based on collectivist traditions regards individual goals as secondary to actions serving to maintain collectivity and conventions (Rózsa, Kő \& Oláh, 2006). Cultural differences determining the development of social behaviour therefore demand the acquisition and efficient operation of specific techniques of socialisation that enable the individual to learn the system of values, rules and norms given by the surrounding culture (Bereczkei, 2003).

Significant variation can be observed, for instance, in the prosocial actions of children growing up in different cultures. In countries where children participate in family and household work at a young age (e.g., Kenya, Mexico, Philippines), children's empathy develops earlier and they show more prosocial actions than in countries where children are not required to help at home (Damon, 1983).

There are several other differences besides the examples discussed above. These also provide convincing evidence for the strong culture-dependence of social behaviour and show that the combined effects of several cultural factors contribute to the development of social competence.

\section{The family}

The main arena of early childhood socialisation is the family (Diener \& Kim, 2004; Fabes, Leonard, Kupanoff \& Martin, 2001). In Schneider's (1993) model, the social behaviour of the child is directly affected by six factors: the social competence of the father and the mother, the child's temperament, parenting style, siblings and the quality of attachment between mother and child. The last of these factors has the strongest effect on the child's social behaviour in later life.

Factors with an indirect effect include social and economic conditions as well as cultural norms and values. The development of children's social competence is also indirectly affected by the interaction and interpersonal relationship network of their parents. Parker, Summerfeldt, Hogan and Majeski (2004) found that social interactions between the parents and other adults and the quality of these interactions had an effect on the social behaviour of the children. The study also revealed that the nature of the parents' relationship with their friends affects their children's peer relationships. The children of fathers who did not show a positive and accepting attitude towards their friends were disliked by their peers and their peers did not want to be friends with them. The children of socially isolated mothers were similarly withdrawn and their peers avoided them and did not want them as friends.

Parents have a decisive role in children's acquisition of forms of social behaviour since their behaviour acts as a model for their children in the processes of imitation, modelling and identification. Bandura (1986) and other researchers representing the theory of social learning argue that every behaviour is shaped by the 
environment. This view contends that children observe that male and female behaviours differ from each other and learn that adults reward or punish the behaviours of boys versus girls differently. Children thus choose behaviours appropriate to their gender that lead to a reward.

There is plenty of evidence that parents not only act as models for their children but also reward or punish behaviours that they consider to be inappropriate for the gender of the child. These results support the basic hypothesis of social learning theory that gender-appropriate behaviours are shaped by the distribution of reward and punishment (Broadhead, Johnston, Tobbel \& Woolley, 2010; Cole \& Cole, 2001).

\section{The school}

After the family, the second most important context influencing the development of social competence in childhood is the school. According to Tunstall (1994), the following elements have a positive effect on students' social competence: a warm and open school climate, clearly stated goals and rules, student-centred learning and teaching, the use of cooperative forms of learning, offering several kinds of learning resources, positive acceptance of the children, teacher control over the students and abundance of interpersonal relationships.

One of the most important participants of the school's social structure is the teacher. Teachers' personal relationships with their students, especially at the early stages of education, when children maintain regular longterm interaction with only one or perhaps a few teachers, are decisive in the development of social behaviours (Hamre \& Pianta, 2001). Teachers' reactions to children's communications and problems also have an impact on students' social behaviours (Chang, 2003; Zsolnai, 2013).

Brotphy-Herb, Lee, Nievar \& Stollak (2007) found a direct relationship between teacher behaviours, the social climate in the classroom and children's social competence. Classroom climate had the strongest effect on both teacher behaviours and children's social competence.

\section{Peer groups}

Children's social behaviours are strongly influenced by their peer group. Peers play a significant role even in early childhood and this effect becomes more and more pronounced as children grow older. Schaffer and Brody (1981) argue that peers assist one another's social development in at least three ways. They may reinforce some types of behaviour and inhibit others. They may act as models signalling the appropriateness or inappropriateness of a given behaviour. They create an opportunity for children to participate as equals in the construction of rules related to individual behaviours.

Children's influence on each other gradually grows from the beginning of school while at the same time the influence of adults gradually wanes (Semrud-Clikeman, 2007; Brown, Odon \& McConnel, 2008). The frequency of prosocial actions also increases with age, especially in lasting peer relationships. Typical manifestations of prosocial behaviour are children sharing their things and helping each other. The more time children spend among peers and friends, the more opportunities they have to rehearse their social roles and learn prosocial behaviours. True friendships and group membership, however, do not really appear until prepuberty, when relationships become stable and are characterised by mutual trust (Cole \& Cole, 2001; Zsolnai, 2013).

Peer interactions foster the development of the social skills that are typically termed social competence in the literature (Cole \& Cole, 2001; Howes, 1987; Zsolnai, 2006). Goodnow and Burns (1985) summarise the most important components of social competence as follows: an ability to initiate, adherence to expectations, flexible adjustment, taking the other's view into consideration, openness towards the other and willingness to 
compromise. The acquisition of these skills assists the development of other social skills needed for relationships that will have a lasting effect on children's social life (Zsolnai, 2006).

\section{Social competence in children with learning disabilities}

Although the generic role played by the micro and macro environment in the development of social competence throughout childhood is applicable to all children, with and without learning disabilities, the practical impact is likely to vary according to the individual needs of the child.

Learning disabilities (LD) can affect a person's ability in the areas of listening comprehension, expressive language, basic reading skills (word identification, phonological coding), reading comprehension, writing language, spelling, mathematics calculation and mathematics reasoning. The majority of childen with learning disabilities probably show significant problems with social competence and emotional adjustment (Semrud-Clikeman, 2007). These children are more likely to show internalizing disorders such as anxiety withdrawal and low self-esteem (Lyon, 1996). Childen with LD have been found to be lonelier and to have fewer mutual friends than those without learning disabilities (Margalit \& Levin-Alyagon,1994).

The focus in this essay is upon the Learning Disability of SpLD/dyslexia which is arguably one of the more contested and controversial additional support needs (ASNs). The involvement internationally of so many people from various disciplines - research, policy and financing - in creating definitions for dyslexia or specific learning difficulties (SpLD/dyslexia) had given rise to over 70 definitions (Rice \& Brooks, 2004) classified as symptom-based, causal-based and/or prognosis-based (Tonnesen, 1997). The United States has adopted the National Institute of Child Health and Development definition for SpLd/dyslexia (sometimes termed Learning Disability in the US) which is said to affect between 4 and 10\% of the population (Shaywitz, 2005): Dyslexia is a specific learning disability that is neurological in origin. It is characterized by difficulties with accurate and/or fluent word recognition and by poor spelling and decoding abilities. These difficulties typically result from a deficit to the phonological component of language that is often unexpected in relation to other cognitive abilities and the provision of effective classroom instruction. Secondary consequences may include problems in reading comprehension and reduced reading experience that can impede growth of vocabulary and background knowledge. (National Institute of Child Health and Development and International Dyslexia Association, 2002).

Unlike many other impairments, it is a hidden difference which commonly emerges as a direct outcome of classroom interaction when an apparently typically developing child fails to acquire literacy and encounters unexpected failure. Rather than exploring the development of social competences, longitudinal studies into internal factors implicated in the development of $\mid \mathrm{SpLD} /$ dyslexia in individuals (e.g. Goulandris \& Snowling, 2001; Snowling, Muter \& Carroll, 2007) have focused upon cognitive, intrapersonal factors and the crucial role of oral language in compensating for phonological deficits. Although low social competence is not an identifying factor for $\mathrm{SpLD} /$ dyslexia and there is much evidence for heightened social skills (Eide \& Eide, 2011; Mortimore, 2008; West,1997), other studies illustrate the potential links between SpLD/dyslexia and intrapersonal cognitive factors crucial to social competence:

- the impact of speech, language and pragmatic deficits on social skills (Csoti, 2001);

- word poverty, reduced literacy acquisition and limited empathy (Wolf, 2008);

- memory issues leading to organisational difficulties, unreliablity and undermining of friendships (Gathercole \& Alloway, 2008); 
- poor automaticity (Nicolson \& Fawcett, 2008) occasioning dyspraxic type difficulties and clumsiness;

- phonological deficits hampering literacy acquisition (e.g. Snowling, 2011) hence exposing the child to failure and humiliation (Mortimore \& Dupree, 2008);

To date studies have placed less emphasis on these potential intrapersonal links, however a growing body of research explores the long term impact of the interaction between children at risk of dyslexia, their classroom climate, their family and peers. Evidence emerges of low general and academic self-esteem and learned helplessness (e.g. Burden, 2005), mental health, depression and socialising issues within and beyond the family (e.g. Scott, 2003); bullying (e.g. Humphrey, 2003); behaviour difficulties (e.g. Mortimore, 2006; 2008) leading to social and educational exclusion and frequently criminality (Macdonald, 2010; 2012). The longevity of damage done to aspirations, trust and relationships by negative classroom interactions (McLoughlin, Leather \& Stringer, 2002; Mortimore, 2006) highlights the crucial role played by all those involved in the school and the need for an inclusive approach.

\section{Inclusive education and social competence development in children with SpLD/dyslexia}

The concept of inclusive education is underpinned by changes in attitudes to disability throughout the twentieth century. In the arena of physical impairment, academics (e.g. Barton, 1996) alleged that the predominant earlier twentieth century 'medical model' of disability had reduced the individual's autonomy and choice, encouraged discrimination, oppression and exclusion from society. This medical model had located disability within personal, biological or cognitive impairments and emphasized individual deficit, expert diagnosis and specialized, separate facilities. The latter half of the twentieth century saw an emergent 'social' model of disability, a switching of focus from the impairment, relieving the individual of the 'problem', and suggesting that it is the physical and conceptual barriers which disable people.

The emerging social model demanded a radical restructuring, not of the individual, but of the educational context (Booth \& Ainscow 2002). Hence the emergence internationally of equal opportunities policy and legislation (Salamanca Statement, UNESCO, 1994; the UK SEN Code of Practice, DfES, 2001) to promote the rights of all children to inclusion within 'mainstream' schools with full access to a broad, balanced and relevant education.

The child's views should be taken into account, parents should play a vital role and emphasis shifted away from 'in-child' medicalized difficulties towards the individual's educational needs, acknowledging the barriers currently preventing children from participating in a rich educational experience alongside their peers. This legislation introduced the concept and reality of the inclusive school described by Bailey (1998, 179 p.) as 'being in an ordinary school with other students following the same curriculum at the same time, in the same classroom, with the full acceptance of all, and in a way that makes the student feel no different to other students'. It is a radical concept which demands a rethink of the ways in which school life, teaching and the curriculum are organized and delivered to create suitable learning support for the whole student population. There are implications for governors, managers, teachers, support staff, parents and children. 
Internationally, professionals and researchers involved with dyslexia were late to reframe this predominantly medical model to include a social perspective (Cooper, 2006b HELYETT Cooper, 2006; Riddick, 2000). This change was delayed by evidence of dyslexic children failing to thrive in mainstream schools in the face of challenges including inappropriate support (Humphrey \& Mullins, 2002), inadequately specialised teachers (Rose, 2009) and bullying (Humphrey, 2003; Scott, 2003). Hence, to procure funding for expert separate provision or specific access arrangements for examinations (Pavey, 2007), the medical discourse tends to survive in the form of ongoing demand in the UK from parents, carers and lobbying groups for 'diagnosis' to enable classification and the preotection of the disability label. However, to hasten the establsihment of inclusive classrooms, the UK Government responded to the needs of dyslexic learners with a drive to develop inclusive practice through an Inclusion Development Programme focused on Dyslexia (ref), incorporating the DyslexiaFriendly Schools initiative

This collaboration between the British Dyslexia Association and the Department for Children, Schools and Families (DCSF, 2008) followed evidence that changing practice to accommodate dyslexic individuals resulted in good practice and improved academic results for all (McKay \& Tresman, 2006). It also acknowledged that learners are at their most vulnerable in educational settings where a premium is placed upon literacy which is likely to be their most vulnerable areas of processing. Classrooms that are not dyslexia-friendly, can transform a learning difference into a deficit (Mortimore \& Dupree, 2008). The programme adopted the principle "if children don't learn from the way we teach, we will teach them in the way they learn" (BDA, 2012) and established criteria for institutions aiming to achieve the BDA Dyslexia-Friendly Quality Mark (Mortimore \& Dupree, 2008; Pavey, 2007). This conforms with Rieser's (2001) vision of a fully inclusive institution moving beyond the model centred upon the 'special' student's need for diagnosis and individualized programs to dismantle barriers and to adapt instructional goals, arrangements, lesson formats, materials, delivery style and classroom so that 'all children can be valued for who they are, can participate, interact and develop their potential' (175. p.).

Guidance for schools and Local Authorities applying for dyslexia-friendly status (BDA, 2006; McKay, 2006) embraces this inclusive ethos and provides criteria. The BDA states that a dyslexia-friendly school is one in which pedagogy, management and attitudes are prepared to change so that 'all pupils are empowered to be "the best they can" with individual approaches to learning recognized and harnessed' (BDA, 2003, p. 11). As Nind (Nind, Rix, Sheehy \& Simmons 2005) states, the inclusive school should:

- Adjust without changing outcomes

- Change instructional arrangements

- Change lesson format

- Change delivery style

- Adapt curricular goals

- Change environment or location

- Change instructional materials

- Perhaps offer personal assistance

- Perhaps offer alternative activity for student and some of his peers but be critical of the messages implicit in differentiation. 
What principles underpin the changes necessary in the dyslexia-friendly inclusive classroom and how can these principles enhance social competence?

The first principle is that everyone should collaborate to recognise the importance of emotional intelligence and the 'feel good factor' - everyone is important and individual differences are recognised and celebrated (McKay, 2006). Older children, in particular, whose dyslexia has been poorly supported are damaged, anxious and resistant (Scott, 2003) - trust and rapport have to be re-established (Edwards, 1994) to restore a positive learning identity and allow the student to take on challenges.

The second principle is that all teachers must analyse the demands made of the dyslexic learners in the classroom by any set task and change the task, or the support offered, to compensate for any barrier to learning it might present. This is not to make the content of the task easier or reduce challenge but to prevent difficulties with literacy, memory or speed of processing from preventing the child from thinking about the content. For example, copying a set of instructions from the board into a homework book involves a complex network of skills which could prevent completion, understanding what is written or following the instructions. This can escalate; behaviour problems emerge as children develop avoidance strategies to protect themselves from exposure to failure and ridicule, which can include anything from biting the child at the next desk to playing the class clown (Mortimore, 2008). Other children may then begin to taunt or avoid them affecting their ability to make friends and social isolation and bullying ensue. Finding an alternative way of getting the homework instructions across - providing a copy, sending an e-mail, organising a study partner to scribe will prevent this escalation from a small individual barrier to a broader problem.

This task analysis underpins the third principle which is to anticipate and avoid unnecessary failure. Structure teaching and organise the classroom to avoid overloading weak areas such as:

- literacy - particularly reading at speed;

- memory - remembering tasks, learned facts, arrangements, especially if under pressure or overloaded;

- speed of processing, retrieving words to answer questions, or completing tasks at speed;

- planning written work and getting thoughts down on paper;

- secretarial skills.

Dyslexic students are likely to be distressed by their failures, by the fact that no one seems to realise how hard they try and bewildered by their perception that everyone else seems to be able to do everything so easily and so quickly. They compare themselves negatively and, often unreasonably, with others and begin to develop a sense of themselves as not being learners - a truly negative learning identity which is reinforced by repeated failure and the way in which teachers label them and their attempts at work (Burden, 2005).

An inclusive dyslexia-friendly classroom will be creative in finding the means, whether it be, for example, ICT use, working with a study partner, providing scribing, to prevent the learner's weaknesses obscuring her knowledge, insight or academic ability in a way that means no dyslexic scientist finds herself barred from the top academic groups because of difficulties with writing or reading scientific terminology (McKay \& Tresman, 2006). Hence the acquired negative learning identity and social difficulties can be gradually transformed into a positive academic self-concept.

The fourth principle is to teach to the student's strengths. An inclusive classroom will encourage both teacher and student to identify their stronger channels and adapt tasks to match their preferences and the context (Riding $\&$ Rayner, 1998). Scaffolded opportunities for learners to develop awareness of their own learning preferences and strengths alongside the encouragement to take responsibility for their choices allow the student to develop 
the effective metacognitive approaches to produce independent learners and combat learned-helplessness (Hattie,

2012). Metacognition is sometimes compromised in dyslexic learners by automaticity difficulties.

Lessons and projects will show evidence of flexible context and teaching approach which offers a full range of multi-modal and multi-sensory strategies, alongside the awareness of the need to individualise. Multimodal and multi-sensory approaches are recommended for dyslexic learners (Ott, 2007) but also successful with typically developing students (Peer \& Reid, 2001). Visual, auditory, practical and kinaesthetic activities enable more learners to be engaged and in depth memory processing to take place (Mortimore, 2008; Kelly \& Phillips, 2011).

The inclusive classroom will make full use of the learners', carefully selected, peers to provide mutual support. The dyslexic scientist can explain how the magnet works to the confused classmate who can read and scribe for both of them. Group and team work on projects can help to establish social bonds and model social skills. Teachers will also depend on classroom assistants and work across the curriculum to help support their dyslexic student in other curriculum areas - a strong element of the dyslexia -friendly school is the rapport and communication that is fostered between students, class teachers, support staff, senior management and parents (McKay, 2006).

Teaching to strengths includes finding effective ways to acknowledge and celebrate children's knowledge. If the student cannot write legibly about his love for and understanding of astronomy, how can the teacher appreciate his knowledge? How can the learner know that he is understood and acknowledged and how can a relationship develop based upon mutual respect? An inclusive classroom will have a marking policy for written work which provides both positive feedback and focused limited points for improvement (Mortimore \& Dupree, 2008). Where the secretarial difficulties obscure the content, alternative arrangements beyond the use of ICT such as voice recognition software could include any of the following: Share with a friend; Bullet points or post-its; Drawings and labels; Flow chart; Comic story board;

Design a quiz; Create a poster, a Time Line, Mind map; make a model; Radio/hot seat interview; create a dance drama; build a volcano/ machine/ bridge and explain how it works. Students will themselves create opportunities which can allow them to impress their peers, work in groups to share and support each other, model effective social skills and promote discussion of learning and the empathy to perceive each other's talents and needs

\section{Conclusion}

Our essay looked at the potential of inclusive education in the fostering of social competence with special emphasis on children struggling with learning difficulties in general and with dyslexia in particular.

The inclusive dyslexia-friendly classroom aims to move the focus away from labelling learners and highlighting difficulties towards observing the differentiated talents and needs of individual learners, adjusting approaches and classroom contexts to offer flexibility in pedagogy, structure, grouping, resources and personnel to ensure that everyone is valued and can access the full curriculum. The social competence of dyslexic learners tends to be compromised more by the potential for negative interaction with teachers, family and peers as an outcome of their literacy acquisition difficulties and their compromised processing skills, rather than intrapersonal deficits. The inclusive dyslexia-friendly classroom offers a model to allow the restoration of positive self-concept and the resulting enhanced social competence. It also has a role to play in supporting the acceptance and social development of all learners, with and without additional support needs.

\section{References}

Bailey, J. (1998). Australia: inclusion through categorisation. In. T.Booth, \& M. Ainscow, (eds): From Them to Us: An International Study of Inclusion in Education. London: Routledge.

Bandura, A. (1986). Social learning theory. London: Prentice Hall.

Barton, L. (ed) (1996). Disability and Society: Emerging Issues and Insights. Harlow: Addison Wesley Longman. 
Bereczkei,T. (2003). Evolúciós pszichológia. [Evolutionary Psychology] Budapest: Osiris Kiadó.

Booth, T., \& Ainscow, M. (2002). Index for Inclusion: Developing Learning and Participation in Schools.

Bristol: Centre for Studies in Inclusive Education (CSIE).

British Dyslexia Association (2006). Achieving Dyslexia-friendly Schools Resource Pack. 5th Edition. Reading: BDA www.bdadyslexia.org.uk accessed 16.11.2012

British Dyslexia Association (2012). http://www.bdadyslexia.org.uk/files/dfs_pack_English.pdf accessed 27.11.2013

Broadhead, P., Johnston, C., T., Tobbel, C. \& Woolley, R. (2010). Personal, social and emotional development. London: Continuum International Publishing Group.

Brotphy-Herb, H. F., Lee, R. E., Nievar, M. \& Stollak, G. (2007). Preschoolers'social competence: Relations to family characteristics, teacher behaviors and classroom climate. Journal of Applied Developmental Psychology, 28, 134-148. doi: 10.1016/j.appdev.2006.12.004

Brown, W. H., Odom, S. L. \& McConnel, S. R. (2008). Social competence of young children. Baltimore: P. H. Brookes Publishing Co.

Burden, B. (2005). Dyslexia and Self-Concept. London: Whurr Publishers.

Cole, M. \& Cole, S. (2001). Fejlödéslélektan. [The Development of Children] Budapest: Osiris Kiadó.

Chang, L. (2003). Variable effects of children's agression, social withdrawal, and prosocial leadership as functions of teacher beliefs and behaviors. Child Development, 74, 535-548. doi: 10.1111/1467-8624.7402014

Cooper, R. (2006). A Social Model of Dyslexia. www.lsbu.ac.uk/lluplus/resources/social_model_dyselxia.shtml accessed 11.11.2012

Csoti, M. (2001). Social Awareness Skills for Children. London: Jessica Kingsley.

Damon, W. (1983). Social and personality development: Infancy through adolescence. New York: W.W. Norton.

Denham, S. A., Blair, K. A., DeMulder, E., Levitas, J., Sawyer, K., Auerbach-Major, S. \&

Queenan, P. (2003). Preschool emotional competence: Pathway to social competence? Child Development, 74, 238-256. doi: 10.1111/1467-8624.00533

Denham, S., Bassett \& Wyatt, T. (2007). The socialization of emotional competence. In. J. E. Gruesec, \& P. D. Hastings,. (eds.), Handbook of socialization. (pp. 614-637) New York: The Guilford Press.

Department for Children, Schools and Families, (2008). Special Educational Needs in England. SFR 15/2008, London.

Department for Education and Skills (2001). Special Educational Needs: Code of Practice of Schools, Early Education Practitioners and Other Interested Parties. Date of Issue: November 2001 Ref: DfES/581/2001 Special Educational Needs Code of Practice.

DfES (2002). Learning and Teaching for Dyslexic Children. www.standards.dfes.gov.uk The Inclusion Development Programme: accessed 15.11.2013.

Diamond, K. E. (2002). The development of social competence in children with disabilities. In. P. Smith, \& C. Hart, (eds.), Blackwell handbook of childhood social development. (pp. 570-587) Malden: Blackwell Publishing. Diener, M. L. \& Kim, D. Y. (2004). Maternal and child predictors of preschool children's social competence. Journal of Applied Developmental Psychology, 25, 3-24. http://dx.doi.org/10.1016/j.appdev.2003.11.006 Edwards, J (1994) The Scars of Dyslexia: Eight case studies in emotional reactions. London: Cassell. Eide, B. \& Eide, F. (2011). The Dyslexic Advantage: Unlocking the Hidden Potential of the Dyslexic Brain. London: Hay House.

Fabes, R. A., Leonard, S. A., Kupanoff, K. \& Martin, C. L. (2001). Parental coping with children's negative emotions: Relations with children's emotional and social responding. Child Development, 72, 907-920.

Forgács, J. (1989). A társas érintkezés pszichológiája. [The psychology of social interaction] Budapest: Gondolat Kiadó.

Gathercole, S. E. \& Alloway, T. P. (2008). Working Memory. A Practical Guide for Teachers. London: Sage.

Goldsmith, H. H. (1987). Roundtable. What is temperament? Four Approaches. Child Development, 58, 505529.

Goodnow, J. \& Burns, A. (1985). Home and school: A child's-eye view. Sydney: Allen \& Unwin.

Goulandris, N. \& Snowling, M. (2001). Dyslexia in adolescence: a five-year follow-up study. In. M. Hunter Carsch, \& M. Herrington, (eds.), Dyslexia and Effective Learning. London: Whurr Publishers.

Greene, M., L., Hariton, J., R. Robins, A., L. \& Fly, B.,L. (2011). Children's social competence. New York: Nova Science Publishers, Inc.

Hamre, B. K. \& Pianta (2001). Early teacher-child relationships and the trajectory of children's school outcomes through eighth grade. Child Development, 72, 625-638. doi: 10.1111/1467-8624.00301

Hattie, J. (2012) Visible Learning for Teachers: Maximizing impact upon learning. Oxon: Routledge.

Herbert-Myers, H., Guttentag, C. L., Swank, P. R., Smith, K. E. \& Landry, S. H. (2006). The importance of language, social and behavioral skills across early and later childhood as predictors of social competence with peers. Applied Developmental Science, 10, 174-187. doi:10.1207/s1532480xads1004_2 
Howes, C. (1987). Peer interaction of young children. Monographs of the society for research in Child Development. 53. (Serial No. 217)

Humphrey, N. (2003). Facilitating a positive sense of self in pupils with dyslexia: the role of teachers and peers. Support for Learning, 18 (3), 129-136. doi:10.1111/1467-9604.00295

Humphrey, N. \& Mullins, P. M. (2002). Personal Constructs And Attribution For Academic Success And Failure In Dyslexia, British Journal Of Special Education, 29(4), 194-201. doi:10.1111/1467-8527.00269

Izard, C. E. (2001). Emotional intelligence or adative emotion? Emotion, 1, (3) 249-257. doi: 10.1037//15283542.1.3.249

Kasik, L. (2010). A szociálisprobléma-megoldó gondolkodás és képesség jellemzői. [Social-problem Solving] In. Zsolnai Anikó \& Kasik László (szerk.): A szociális kompetencia fejlesztésének elméleti és gyakorlati alapjai. (pp. 97- 114) Budapest: Nemzeti Tankönyvkiadó.

Kelly, K. \& Phillips, S. (2011). Teaching Literacy to Learners with Dyslexia - a multisensory approach. London: Sage.

Kopp, M. \& Skrabski, Á. (1995). Alkalmazott magatartástudomány. [Applied behavioural sciences] Budapest:Corvinus Kiadó.

Macdonald, S. J. (2010). Dyslexia and Crime: a social model approach: Saarbrücken: VDM Ltd.

Macdonald, S. J.(2012). Biographical Pathways into Criminality: Understanding the Relationship between Dyslexia and Educational Disengagement. Disability and Society, 27 (3), 427-44.

McKay, N. (2006). Removing Dyslexia as a Barrier to Achievement: The Dyslexia Friendly Schools Toolkit Oxford: SEN marketing

McKay, N. \& Tresman, S. (2006). Achieving Dyslexia-Friendly Schools. Oxford: SEN Marketing.

McLoughlin, D., Leather, C. \& Stringer, P. (2002). The Adult Dyslexic Interventions and Outcomes. London: Whurr Publishers.

Mortimore, T. (2006). The Impact of Dyslexia and Cognitive Style upon the Study Skills and Experience of Students in Higher Education. Cardiff University: Unpublished Doctoral Dissertation.

Mortimore, T. (2008). Dyslexia and Learning Style: A Practitioner's Handbook Second Edition. Chichester: Wiley-Blackwell.

Mortimore, T. \& Dupree, J. (2008). Dyslexia-friendly practice in the Secondary Classroom. Exeter: Learning Matters.

Nagy, J. (2000). XXI. század és nevelés. [Education and the 21th century] Budapest: Osiris Kiadó.

Nagy, J. (2007). Kompetenciaalapú kritériumorientált pedagógia. [Criterion referenced pedagogy] Szeged: Mozaik Kiadó.

National Institute of Child Health and Development and International Dyslexia Association, (2002). Retrieved from http://www.interdys.org/FAQWhatIs.htm January 2013

Nicolson, R. I. \& Fawcett, A. J. (2008). Dyslexia, Learning and the Brain. MIT, London.

Nind, M., Rix, J., Sheehy,K. \& Simmons, K. (2005, eds.). Curriculum and Pedagogy in Inclusive Education. Values into Practice. Oxford: Routledge Farmer.

Odom, S. L., Zercher, C., Li, S., Marquart, J. M., Sandall, S. \& Brown, W. H. (2006). Social acceptance and rejection of preschool children with disabilities: A mixed-method analysis. Journal of Educational Psychology, 98, 807-823. doi: 10.1037/0022-0663.98.4.807

Ott, P. (2007). Teaching Children with Dyslexia. A practical guide. Routledge, London.

Parker, J. D. A., Summerfeldt, L. J., Hogan, M. J. \& Majeski, S. A. (2004). Emotional intelligence and academic success: examining the transition from high school to university. Personality and Individual Differences, 36, 163-172.

Pavey, B. (2007). The Dyslexia-friendly Primary School. London: Paul Chapman Publishing

Peer,L. \& Reid, G. (2001, eds.). Dyslexia and Successful Inclusion in the Secondary School., London: David Fulton.

Rice, M. \& Brooks, G. (2004). Developmental Dyslexia in Adults: A research review. London: NDRC.

Riddick (2000). Dyslexia and Inclusion: time for a social model of disability perspective? International Studies in Sociology of Education, 11(3), 223-236. doi:10.1080/09620210100200078

Riding, R. \& Rayner, S. (1998). Cognitive Styles and Learning Strategies. London: David Fulton.

Rieser, F. (2001). The Struggle for Inclusion: The growth of a movement, In. Barton, L. (ed.), Disability, politics and the struggle for change, London: David Fulton.

Rose, S. J. (2009). Identifying and Teaching Children and Young People with Dyslexia and Literacy Difficulties An independent report. www.education.gov.uk/publications/ accessed 12. 09. 201.

Rose-Krasnor, L. (1997). The nature of social competence: A Theoretical review. Social Development, 6, 111135. doi: 10.1111/j.1467-9507.1997.tb00097

Rózsa, S., Kö, N. \& Oláh Attila (2006). Rekonstruálható-e a Big Five a hazai mintán. [Can the BFQ be reconstructed on Hungarian sample] Pszichológia, 26 (1), 57-76. 
Saarni, C. (1999). Emotional competence and self-regulation in childhood. In. Salovey, P. \& Saarni, C. (1999), The development of emotional competence. New York: Guilford Press.

Schaffer, D. \& Brody, G. H. (1981). Parental and peer influences on moral development. In. R. W. Henderson, (eds.), Parent-child interaction. Academic Press.

Schneider, B. H. (1993). Children's social competence in context. Oxford: Pergamon Press.

Scott, R. (2003). Dyslexia and Counselling. London: Whurr Publishers.

Semrud-Clikeman, M. (2007). Social competence in children. New York: Springer.

Shaywitz, S. E . (2005). Overcoming Dyslexia: New York: Alfred A. Knopf.

Snowling, M J (2011). Beyond Phonological Deficits: Sources of Individual Differences in reading Disability In. S. A. Brady, Braze, D. \& A. Fowler, (eds): Explaining Individual Differences in Reading. London: Psychology

Press.

Snowling, M.J., Muter, V. \& Carroll, J.M. (2007). Children at family risk of dyslexia: a follow-up in

adolescence. Journal of Child Psychology \& Psychiatry, 48, 609-61.

Stephens, T. (1992). Social skills in the classroom. Odessa: PAR.

Thomas, A. \& Chess, S. (1977). Temperament and development. Bruner/Mazel, New York.

Tonnesen F.E. (1997). How Can We Best 'Define' Dyslexia? Dyslexia, 3, 78-92.

Tunstall, D. F. (1994). Social competence needs in young children: What the research says. New Orleans: Paper presented at the Association for Childhood Education

UNESCO (1994). The Salamanca Statement: A Framework for Action. UNESCO. Salamanca

West, T. (1997). In the Mind's Eye. Visual Thinkers, Gifted People with Learning Difficulties, Computer Images and the Ironies of Creativity ( ${ }^{\text {nd }}$ Edition) Buffalo, NY: Prometheus Books.

Wolf, M. (2008). Proust and the squid: the story and science of the reading brain. Cambridge: Icon.

Zsolnai, A. (2006). A szocialitás fejlesztése 4-8 éves életkorban. [Developing social skills in childhood: Ages 4 to 8 Years] Szeged: Mozaik Kiadó.

Zsolnai, A. \& Kasik, L. (2007). Az érzelmek szerepe a szociális kompetencia müködésében. [Emotions and the functioning of the social competence] Új Pedagógiai Szemle, 57 (7-8), 3-16.

Zsolnai, A. (2013). A szociális fejlődés segítése. [Helping of social development]

Budapest: Gondolat Kiadó. 